\title{
WORKSHOPS CONVENED BY THE INTERAGENCY COMMITTEE ON SEISMIC SAFETY IN CONSTRUCTION DURING 1984
}

Edgar V. Leyendecker George E. Turner

S. George Fattal

Center for Building Technology U.S. Department of Commerce National Bureau of Standards Gaithersburg, MD 20899

May 1985

Prepared for use by:

Interagency Committee on Seismic Safety in Construction

Sponsored by:

Federal Emergency Management Agency Washington, DC 20472 

WORRSHOPS CONVENED BY THE INTERAGENCY COMMITTEE ON SEISMIC SAFETY IN CONSTRUCTION DURING 1984

EGgar V. Leyendecker

George E. Turner

S. George Fattal

Center for Building Technology

Nuational Bureau of Standards

U.S. Department of Commerce

Gaithersburg, MD 20899

May 1985

Prepared for use by:

Interagency Committee on Seismic Safety in Construction

Sponsored by:

Federal Emergency Management Agency

Washington, DC 20472 

CONTENTS

Page

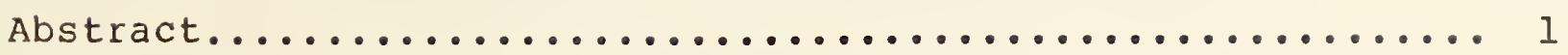

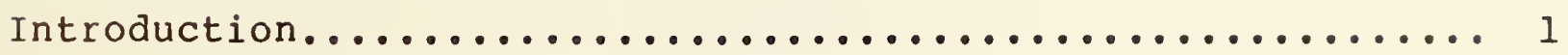

Workshop on Implementation of Federal Seismic Provisions in

the Building Programs of Federal Agencies - March 19, 1984... 3

Workshop on Lifelines - March 20, 1984................. Il

Workshop on Seismic Zoning - March 21, 1984............ 15

Workshop on Evaluation of Existing Buildings -

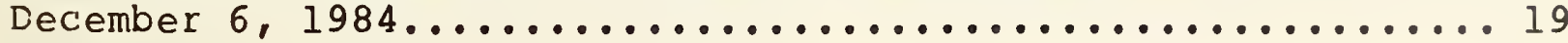

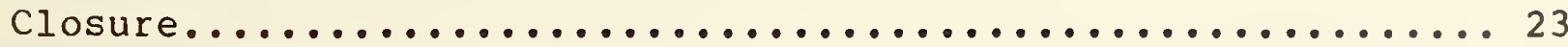

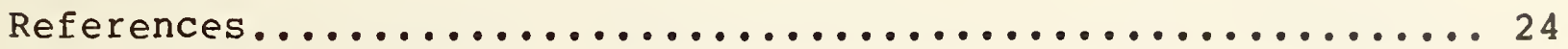





\section{WORRSHOPS CONVENED BY THE INTERAGENCY COMMITTEE ON SEISMIC SAFETY IN CONSTRUCTION DURING 1984}

\section{ABSTRACT}

In an effort to inform Federal agencies about the most recent development on various earthquake hazards mitigation topics, informal workshops were convened by the Interagency committee on Seismic Safety in Construction in washington. DC during 1984. This report presents summaries of the workshop series which included the subjects of implementation of seismic provisions for Federal buildings, lifelines, seismic risk maps, and evaluation of existing buildings. The summaries provide an overview of the major topics discussed. Where applicable, recommendations that resulted are given.

Key words: Buildings; building design; codes and standards: earthquake; existing buildings: Federal workshops: lifelines; seismic zoning

\section{INTRODUCTION}

Earthquakes have caused, and can cause in the future, enormous loss of life, injury, destruction of property, and economic and social disruption. Such losses, destruction, and disruption can be reduced substantially through the development and implementation of earthquake hazards reduction measures. Recognizing these needs, the Congress passed the Earthquake Hazards Reduction Act of 1977 (P.L. 95-124), and the National Earthquake Hazards Reduction Program (NEHRP) was established the following year. The Act and the NEHRP acknowledge that the Federal government must set an example for others to emulate by its own actions, including the institution of more effective hazards mitigation measures in its own facilities.

The NEHRP established the Interagency Committee on Seismic Safety in Construction (ICSSC) in 1978 to assist the Federal departments and agencies involved in construction to develop earthquake hazards reduction measures and to incorporate them in their ongoing programs. These measures will be based on nationally recognized standards and practices to the extent feasible and consistent with Federal responsibilities.

In an effort to use the most recent developments on various earthquake hazards mitigation topics, four educational workshops were convened by the ICSSC in Washington, DC during 1984. The workshop series included the subjects of (1) implementation of seismic provisions for Federal buildings, (2) lifelines, (3) seismic risk maps, and (4) evaluation of existing buildings. 
The workshops provided a forum for presenting and discussing the seismic regulations and policies of Federal agencies; presenting and discussing current research in earthquake engineering; discussing implications of the various seismic source zones; and discussing recommendations for seismic regulations and policies of Federal agencies.

The summaries provide an overview of the topics discussed. Where applicable, recommendations are given. 
WORKSBOP ON IMPLEMENTING FEDERAL SEISMIC PROVISIONS IN THE BUILDING PROGRAMS OF FEDERAL AGENCIES - MARCH 19, 1984

Participants (A list of agency acronyms is included in table 1.)

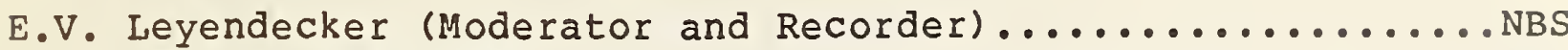

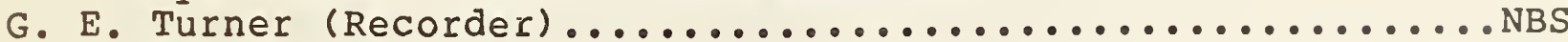

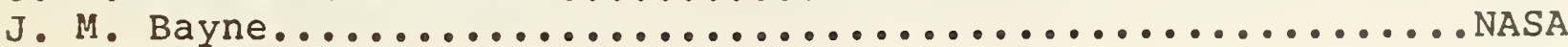

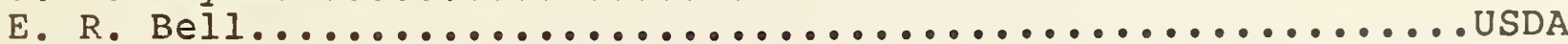

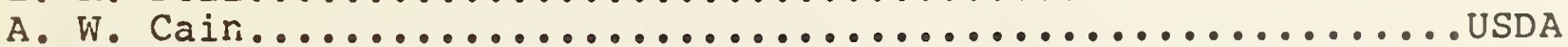

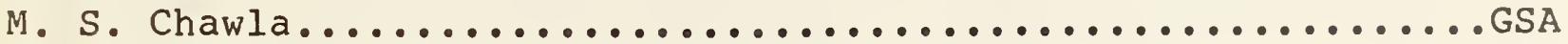

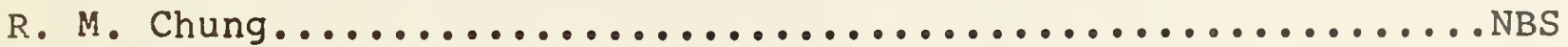

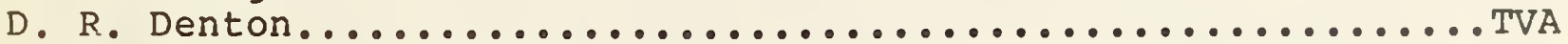

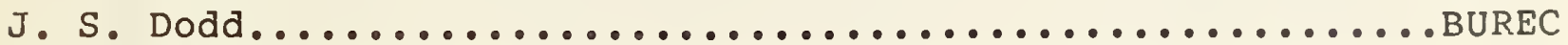

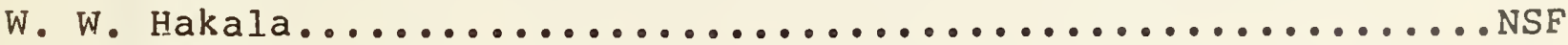

J. R. Hill...................................... DOE

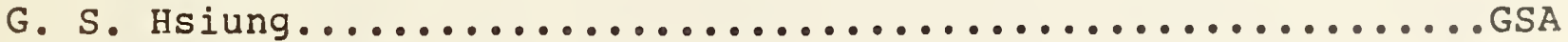

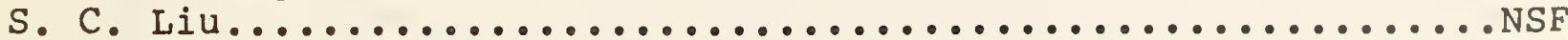

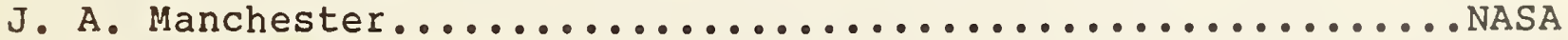

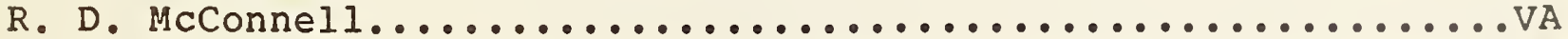

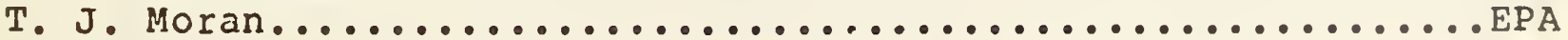

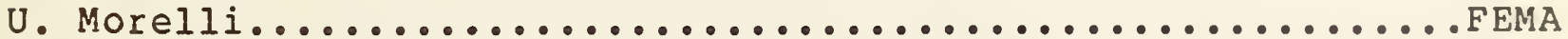

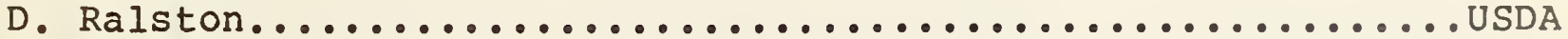

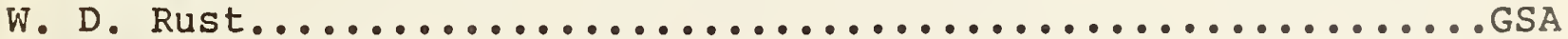

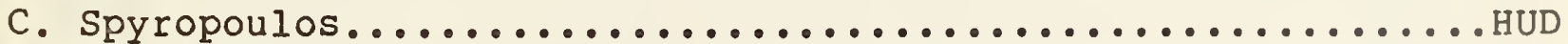

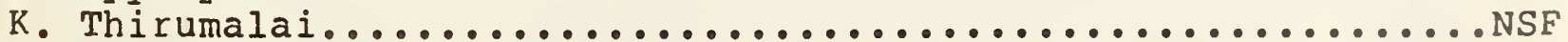

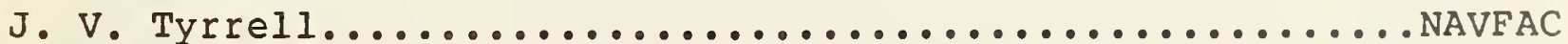

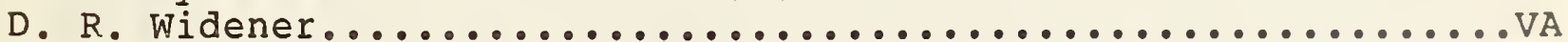

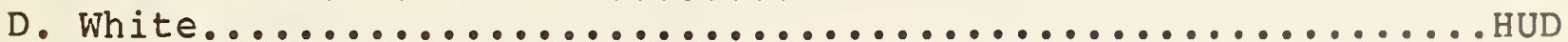

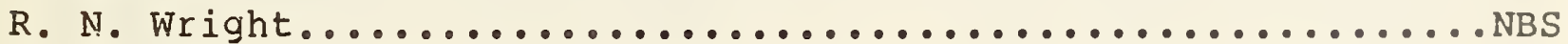

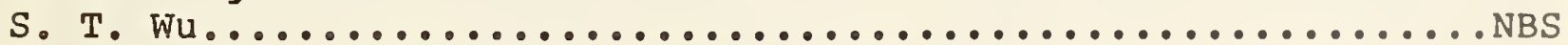

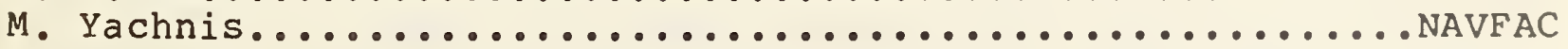

\section{WORRSHOP HIGHLIGHTS}

The workshop was sponsored by the ICSSC Subcommittee on Standards for New and Existing Buildings (Subcommittee I) and moderated by its chairman Edgar V. Leyendecker. The workshop objective was the identification and evaluation of the effects of current Federal agency policy and requirements on the adoption and use of Federal seismic design provisions, and the development of recommendations for implementing uniform provisions considering agency requirements.

The first half of the morning session included a presentation by Leyendecker that gave an overview of existing seismic codes and standards and their use in the private sector. The second half of the morning session included presentations by seven Federal agencies concerning their seismic policy and requirements. The overview is presented below in some detail since it sets the stage for this and other workshops. 
Seismic risk varies throughout the U.S. and seismic design criteria frequently use zone maps such as the one in figure 1 as a measure of risk. The seismic risk is smallest for zone 0 and largest for zone 4. Design criteria do not change within a zone.

The majority of construction in the U.S. is undertaken by the private sector and regulated by local government. These local regulations are in turn, based largely on provisions of one of the three model building codes and/or voluntary national standards. Regulations for Federal buildings tend to be similar to the model codes and national standards, and in some instances, defer to local requirements. Some Federal agencies' policies are described by representatives of the Federal agencies later in this workshop summary. The following material is background for their presentations and for several of the subsequent workshops.

\section{Structural Engineers Association of California (SEAOC)}

The report "Recommended Lateral Force Requirements and Commentary," prepafed by Structural Engineers Association of California [15] contains requirements which

"are intended to provide criteria to fulfill life safety concepts. It is emphasized that the recommended design levels are not directly comparable to recorded or estimated peak ground accelerations from earthquakes. They are, however, related to the effective peak accelerations to be expected in seismic events. More specifically with regard to earthquakes, structures designed in conformance with the provisions and principles set forth therein should, in general, be able to:

1. Resist minor earthquakes without damage:

2. Resist moderate earthquakes without structural damage, but with some nonstructural damage:

3. Resist major earthquakes, of the intensity of severity of the strongest experienced in California, without collapse, but with some structural as well as nonstructural damage.

In most structures it is expected that structural damage, even in a major earthquake, could be limited to repairable damage. This, however, depends upon a number of factors, including the type of construction selected for the structure."

l Numbers in brackets refer to references at the end of the text. 
Most current seismic design criteria can be traced to the SEAOC recommendations. Inherent in this design approach is the acceptance of inelastic behavior of the building structure. Some damage is anticipated although the extent aepends on the magnitude of the earthquake. Although this is the normal philosophy for building design, it might not be acceptable in all instances. Buildings which must remain functional following an earthquake, such as a hospital, require extra consideration.

The following description of the technical requirements of the SEAOC recommendations is similar to that given by Forell [10]. The basic design procedure involves determination of an equivalent static base shear ${ }^{2}$ which is applied to the structure in a specified manner. The design formula for the base shear, $V=$ ZIKSCW, takes into consideration the seismicity of the area (z), the importance of the structure (I), the type of the lateral resisting system ( $R$ ), the response of the structure (C), which is related to its fundamental period of vibration, the site structure interaction (S), and the effective inertial mass of the structure (W). The recommendations have provisions for the vertical and horizontal distribution of the base shear force that take into consideration the higher modes of vibration in the vertical distribution, torsional forces due to eccentricities, and overturning. Limitations are also placed on allowable drift. Three recommendations cover performance of structural systems by establishing minimum limits of ductility, deformation, compatibility, and special detailing requirements. Specific requirements are included for concrete ductile moment-resisting space frames, concrete shear walls and braced frames, and steel ductile moment-resisting space frames.

In the formula for computation of base shear, the coefficient $z$ varies to reflect the seismicty of the region (zone) in which the building is being designed. The SEAOC criteria do not contain specific recommendations for values of $Z$ other than $a$ value of 1.0 for areas of highest seismicity. Other design criteria do contain recommendations for $\mathrm{z}$ which depend on the seismic zone obtained from a zone map. These recommendations are discussed later for the specific criteria.

The factor I varies between 1 and 1.5 depending upon the function of the structure. A building such as a hospital has an importance factor of 1.5 .

\footnotetext{
${ }^{2}$ Many typical buildings can be designed using a static analysis approach. Although a dynamic analysis may be required in some instances, its primary benefit is to determine a better distribution of forces on the building rather than to alter the total base shear.
} 
A major resource document is the "Tentative Provisions for the Development of Seismic Regulations for Buildings" [4] (prepared by the Applied Technology Council, and published by the National Bureau of Standards and subsequently referred to as the ATC Provisions). This report was published in 1978 as a state-ofthe-art document for seismic design.

The ATC Provisions, like the SEAOC criteria, involve computation of a total base shear which is then distributed on the structure in a prescribed manner. However, the equations for computation of the base shear and the distribution of the base shear are different from SEAOC. The base shear formula $V=C_{S} W$ is a function of the seismic design coefficient $\left(C_{S}\right)$ and the effective inertial mass of the structure $(W)$. Two equations are provided for computation of the coefficient $\mathrm{C}_{\mathrm{S}}$. Although the two equations are different, both of them involve the use of a response modification factor that is a function of the construction type and material and a factor representing the seismic intensity.

The response modification factor serves a purpose similar to the $K$ factor in the SEAOC criteria. It varies according to the lateral load resisting system and is selected to allow inelastic behavior similar to that allowed by SEAOC.

Two maps are provided for determination of the seismic intensity factor, one in terms of effective peak acceleration and the second in terms of effective peak velocity-related acceleration. Each map is divided into seven map areas (the larger the number the higher the risk), the effective peak velocity-related acceleration map is shown in figure 2. The map areas are defined by county lines in an effort to simplify difficulties associated with crossing of political boundaries. Since the map areas are based on accelerations, which in turn provide the basis for the lateral force equations, the design base shear is related to realistic ground motion intensities. These map areas do not correspond to the zone map used to determine the $z$ factor. They can, however, be related as in table 2 . The numbers are also not directly related to other measures of intensity such as the Modified Mercalli scale.

The ATC Provisions do not use an importance factor to account for the occupancy or critical nature of a building. Instead, the Provisions divide buildings into three Seismic Hazard Exposure Groups which consider these factors. A bujlding is rated as falling into a specific exposure group depending on its use and this rating is combined with a seismicity Index, which is dependent upon the seismic map area, and used to determine a Seismic Performance Category applicable for the structure. The Seismic Performance Category then spells out design and detailing 
requirements. The more important a structure and the higher the seismicity, the more stringent the design and detailing requirements become.

The report with amendments [3] has been evaluated by the Building Seismic Safety Council in a national trial design program [14]. The Building Seismic Safety Council (BSSC) has published revised provisions following the conclusion of the trial design program [5]. These provisions are currently being balloted by the BSSC.

National Standards

The American National Standards Institute publishes the ANSI A58.1-1982 "Minimum Design Loads for Buildings and Other Structures" [13] the only voluntary national loading standard in the United states. The standard contains requirements for earthquake loads that are suitable for inclusion in building codes and other design documents. The earthquake load requirements, as in the case for other design approaches, assume that inelastic behavior of the building will occur. Accordingly, earthquake design requires knowledge of the material behavior as well as the applied loads. Since the ANSI standard is a loads document, it provides limited guidance on material behavior. Other national standards such as that published by the American Concrete Institute [7] for reinforced concrete design, must be selected for the specific material type. The seismic design requirements contained in ANSI A58.1-1982 are similar to those contained in the SEAOC recommendations and in the Uniform Building Code [18] and parts of the report "Tentative Provisions for the Development of Seismic Regulations for Buildings." The seismic risk map used in the ANSI A58.1-1982 standard is based on work performed in developing the ATC Provisions. Specifically, the information used in developing the ATC map in figure 2, was used in developing the ANSI map shown in figure 1. In order to maintain consistency with current earthquake design practice, the ANSI map was divided into zones $0-4$ for purposes of selection of the zone coefficient $z$. The $\mathrm{Z}$ coefficients are shown in table 3 .

\section{Model Codes}

There are three model codes in the United states. These are the model codes published by the International Conference of Building officials - Uniform Building Code; Building Officials and Code Administrators International, Inc. - Basic Building Code; and Southern Building Code Congress International, Inc. Standard Building Code. The Basic Building Code and the standard Building Code contain seismic provisions that are based on the ANSI A58 standard. However, the 1972 edition of ANSI A58 [6] is referenced rather than the more recent 1982 edition [13]. There are a number of differences between the two editions of the ANSI Standard. A major difference is the map in the 1982 edition 
which is based upon risk while the 1972 edition uses a map based on information available in 1968 on the maximum size earthquake. The equation for base shear in the 1982 edition also includes the importance factor, I, which was not used in the earlier version.

The Uniform Building Code (UBC) contains seismic design requirements which, for the most part, are based upon the recommendations of the Structural Engineers Association of California. The base shear equation used in the UBC is essentially the same as that used in the SEAOC recommendations and in the ANSI Standard. However, the zone map used in the UBC is based upon the maximum earthquake which has occurred in a region and thus has different boundaries from the map used by ANSI. This zone map is shown in figure 3. The principal difference between the two maps is that the ANSI map reduces the required $z$ factor (used in computing base shear) for many areas, particularly in the eastern portion of the U.S. The ANSI committee also adopted a $Z$ factor of $1 / 8$ for zone 0 rather than the value of 0 used in UBC. This was done to allow removal of certain specific material requirements from the standard. Other minor differences exist but these are not discussed here.

These design guidelines and maps provide a background for discussion of agency requirements. They apply primarily to buildings - little is available for lifelines. The variation in requirements and maps identify some of the difficulties in achieving uniformity, among the agencies. Some agency practices are discussed below.

\section{Draft Seismic standard for Federal Buildings}

In 1981 a draft standard [11] containing provisions for the reduction of earthquake hazards in Federal buildings was published. One purpose of the draft was to provide a uniform standard for use by all Federal agencies for the planning, design, and construction of buildings, both within and outside the United states. This was required as part of the NEHRP.

The standard was prepared by representatives of Federal agencies as an adaptation of existing voluntary standards, model building codes, Federal regulations, and research reports. The standard is most closely related to the 1979 Uniform Building code. Although there are many differences with the UBC, owing to different contexts, policies, and styles, the basic technical approach to the analysis of seismic loads and the design of buildings to resist such loads is the same. Substantial use was also made of the "Tentative Provisions for the Development of Seismic Regulations for Buildings" and ANSI A58.1-1982. The zone map is the same as in this standard. The seismic regulations of the Veterans Administration, Army, Navy, Air Force, General Services Administration, and Department of Housing and Urban Development were all considered in the development of this standard. 
The draft standard is primarily intended for new buildings. structures that are not associated with buildings are outside the scope because their particular functional requirements and the nature of hazard they present were not considered in developing the requirements of the standard and because the idealization of seismic loadings presented in this standard may not be an appropriate model for predicting their physical response to seismic ground shaking. Another exception is that buildings and structures associated with nuclear power plants are subjected to the more rigorous standards of the Nuclear Regulatory Commission.

Richard McConnell reported that the Veterans Administration (VA) uses seismic provisions [12] that are recommended by an advisory committee to the VA. The result of the committee's recommendations is a set of seismic provisions similar to those in the Uniform Building Code (UBC). VA criteria requires site specific determination of ground motion. Additions, deletions and changes to the VA's seismic provisions may be recommended by its advisory committee. Local requirements are also considered and, if more stringent, are used instead of the VA criteria.

Michael Yachnis reported that the Department of Defense (DOD) uses the seismic provisions in the Tri-services Manual [16]. The provisions are similar to those in the UBC and are supplemented with construction details. Yachnis pointed out that each branch of the services also has its own design manual for medical facilities. Additions, deletions, and changes to the Manual, along with deviations from it, are made by an ad hoc DOD committee.

James Hill reported that the Department of Energy (DOE) uses the seismic provisions in its own design procedures. The DOE provisions require the same levels of design as does the UBC. A separate set of provisions is used for nuclear power plant and test facility designs. Additions, deletions and changes to the seismic provisions must be evaluated and recommended by a board within DOE.

William Rust reported that the General Services Administration (GSA) uses its own design guide [8] that contains seismic provisions based on design levels one, two, and three of the UBC. Additions, deletions and changes to the provisions are accommodated through GSA Public Buildings service review and approval.

David Ralston reported that the Department of Agriculture (DOA) reference existing codes and standards in lieu of developing their own. Within the DOA, the Soil Conservation Service, Forest Service, Farmers Home Administration, and the Rural Electrification Administration all use or require the use of seismic provisions. Additions, deletions and changes to the codes and 
standards in use are accommodated through DOA review and approval.

Constantine Spyropoulos reported that the Department of Housing and Urban Development (HUD) references the 1973 UBC [17] seismic zone map and ANSI A58.1-1972 in its minimum property standards. In situations where local codes have more stringent requirements than the HUD references, they supersede those references. Additions, deletions and changes to the references are accommodated through HUD review and approval plus publication in the Federal Register.

Thomas Moran reported that the Environmental Protection Agency (EPA) defers to the use of state and local codes as applicable. References to state and local codes are contained in an EPA handbook of procedures. In order for EPA to establish its own seismic provisions, an executive order would be required.

The afternoon session included discussions on the feasibility and method of implementing uniform seismic design provisions for Federal buildings. As part of the afternoon session, each agency representative to the ICSSC was requested to provide the information shown in tables 4 and 5 . Analysis of the submissions indicated that the majority of the agencies that designed and occupied buildings used criteria similar to that contained in the Uniform Building Code. Agencies which leased buildings or constructed them under grant programs tended to use local building codes. The majority of the agency representatives agreed that common Federal seismic provisions are desirable provided they allowed flexibility for agency requirements. Common provisions would eliminate such things as different design standards being used by different agencies constructing or regulating construction within the same seismic zone.

The discussion resulted in the following recommendations:

1. FEMA should draft an executive order requiring agencies to adopt common seismic provisions for new buildings.

2. The order should be flexible to allow for the inclusion of the differing special requirements of the various agencies.

3. The order should reference the Draft Seismic Standard developed by the ICSSC Subcommittee 1 as the common seismic provision.

4. Only one agency should publish the Draft Seismic Standard in its announcement in the Federal Register and all other agencies should reference its original publication in their annoucements. 


\section{Participants}

C.F. Scheffey (Moderator)...........................DOT

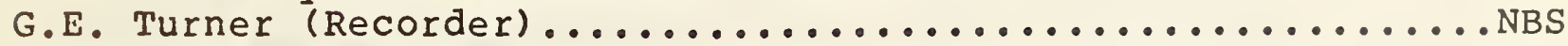

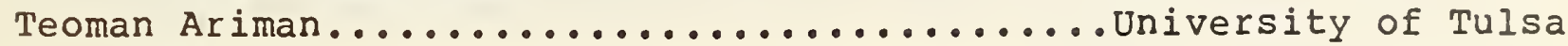

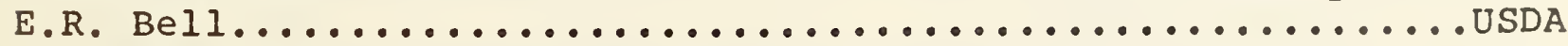

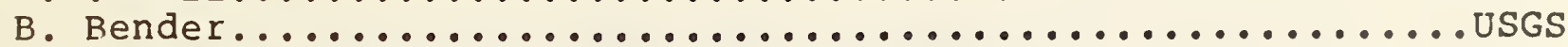

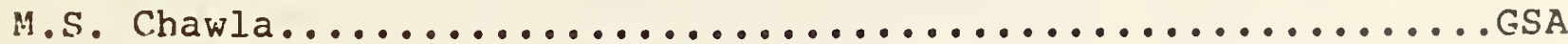

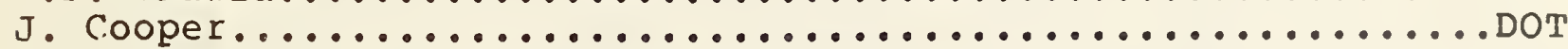

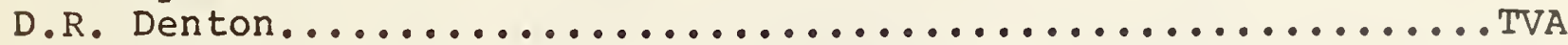

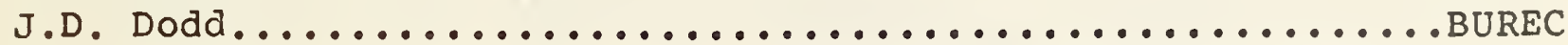

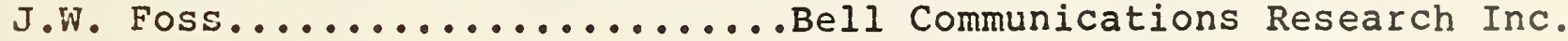

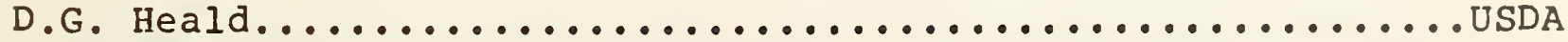

J.R. Hill.................................... DOE

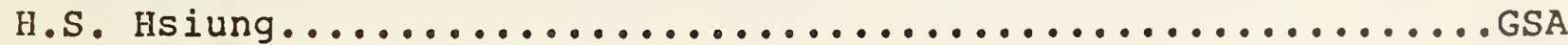

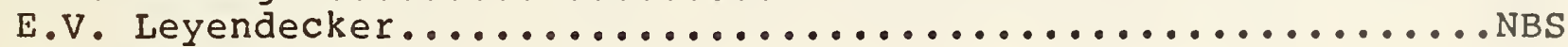

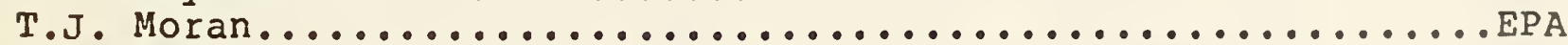

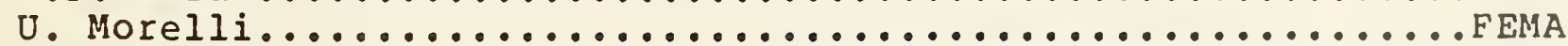

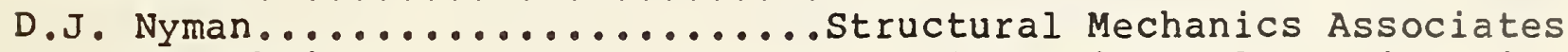

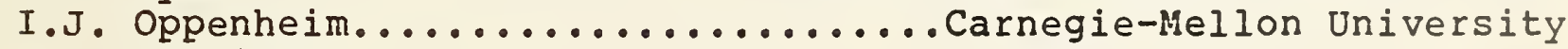

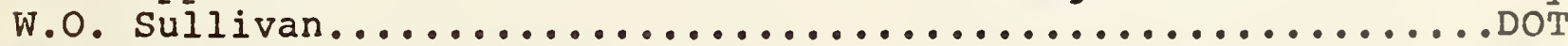

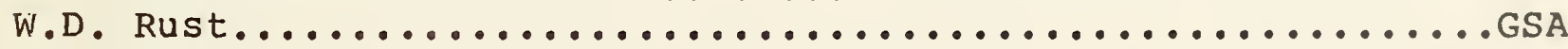

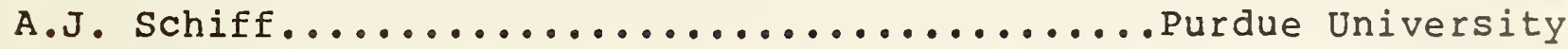

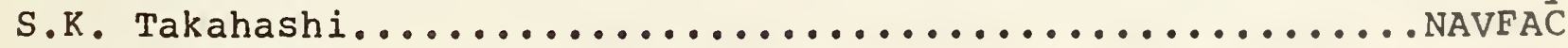

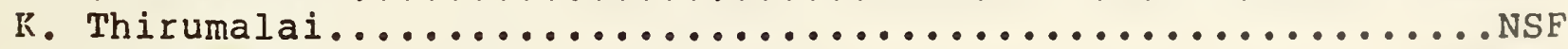

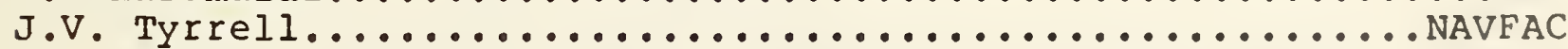

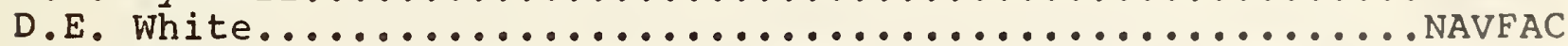

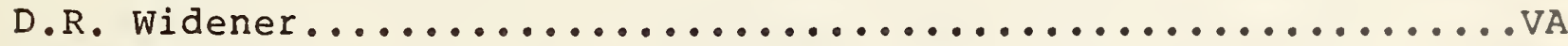

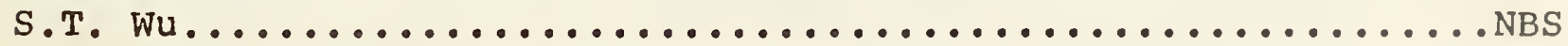

\section{WORKSHOP HIGHLIGHTS}

The workshop was sponsored by the ICSSC Subcommittee on Lifelines (Subcommittee 2) and moderated by its chairman, Charles F. Scheffey. He opened the workshop with a general introduction to the ICSSC and gave an overview of the scope and character of lifeline systems.

Ugo Morelli gave an overview of the Federal Emergency Management Agency (FEMA) and the lead agency support that FEMA provides the ICSSC. In addition, Morelli described FEMA's programs in seismic design, earthquake preparedness, and community education.

K. Thirumalai reported on the types of earthquake engineering research being supported by the National Science Foundation (NSF). Current funding categories are siting and geotechnical earthquake engineering; lifeline earthquake engineering research; and lifeline system locations. The primary issues associated with lifelines research are: 
1. The complexity and diversity of lifeline earthquake engineering.

2. The assessment of research priorities.

3. The lack of techniques for simulating earthquake damage

to lifeline systems.

4. The need to establish a lifelines data base.

Thirumalai's presentation prompted a discussion among the participants about the lack of design data and guidelines available on the topic of lifeline engineering.

Douglas Nyman reported on the activities of ASCE's Technical Council on Lifeline Earthquake Engineering (TCLEE). Nyman mentioned four major lifeline categories: energy, water, transportation, and communication. TCLEE is composed of committees for carrying out the Council's business and to address the lifeline categories. TCLEE committees are:

1. Executive Committee

2. Investigation Committee

3. Program and Publication Committee

4. Electric Power and Communications Committee

5. Gas and Liquid Fuel Committee

6. Seismic Risk Committee

7. Transportation Committee

8. Water and Sewage Committee.

Ansel Schiff gave a presentation on the earthquake-resistant design of electrical power facilities. Schiff pointed out that while earthquake risks vary geographically, as do the accompanying costs of providing earthquake resistance, in all locales there are simple, economical precautions that can be taken. For example, providing inexpensive restraints on small items and storage units that may fall or tip over as a result of ground motion.

Schiff suggested that power facility damage resulting from an earthquake would be more severe in low risk areas because of the possible "laissez faire" attitude toward seismic design in those areas. On the other hand, a state such as California should suffer less severe damage to its power facilities because 
of the statewide emphasis on seismic design. Consequently, the possible severity of damage to power facilities varies inversely to the level of earthquake risk throughout the U.S.

Schiff also pointed out that the porcelain commonly used for insulating functions at power facilities is frequently damaged as a result of ground motion.

John Foss of Bell Laboratories reported that as a result of the Bell system divestiture, Bell Laboratories are now part of AT\& $T$ and therefore no longer establish seismic requirements for the seven regional telephone companies. The regional companies are responsible for implementing seismic hazard reduction measures. Foss pointed out that the telephone system is not as susceptible to earthquake damage as other lifelines because underground cables are flexible and can deform without being damaged, and alternate paths around damaged parts of the network are readily available.

Foss provided examples of specific actions taken to mitigate seismic hazards. Computer equipment is secured to the slab below raised floors, battery backup power sources are braced and strengthened, site control and service restoration planning is undertaken, and network management strategies are developed. The telephone companies develop their earthquake survivability procedure according to the risks associated with one of the four seismic zones as shown in figure 1 .

Teoman Ariman of the University of Tulsa gave an overview of the ASME Task Group on Lifelines and Earthquake Engineering. The Task Group is guided by an ASME Advisory Committee, and it cooperates with Japanese lifeline engineering researchers through an active program of translating and disseminating Japanese research reports. Ariman showed the locations of pipeline failures that have occurred along a portion of the San Andreas fault, and he presented a series of design strategies for pipelines that cross faults.

Irvin Oppenheim of Carnegie-Mellon University discussed the conduct of seismic risk analysis for lifelines. He pointed out that in order to develop a data base reflecting the consequences of an earthquake, it is necessary to determine what is important to measure and how it is to be measured.

In order to determine risk, Oppenheim said that there must be the capacity to make a statement such as: "For lifeline ' $x$ ' the annual probability of suffering ' $y$ ' is equal to ' $z$ '." He suggested that measures of damage might be expressed in terms of connectivity, maximum flow, serviceability, or economic loss.

Special issues that should be considered in a risk analysis of a lifeline are: 
1. Regional dependencies.

2. Possible bottlenecks and their locations.

3. Repair period length.

4. System redundancy.

5. Capability for consequence mitigation by management.

James Cooper, at the time with the Federal Highway Administration, discussed the survivability of ground transportation facilities. Cooper pointed out that many current code provisions for roads and bridges resulted from the effects of earthquakes that have occurred between 1906 (San Francisco) and 1933 (Long Beach). Roads and bridges can be designed to withstand earthquakes either by intuition or by using empirical data. Mr. Cooper proceeded to show examples of road and bridge failures.

According to Cooper, the uncertainties associated with earthquake-resistant design are the nature of potential ground motion; the structural response to the ground motion; and the level of risk that is undesirable. The extent of upgrading the seismic resistance capabilities of existing roads and bridges is based on the risk to the structures, their importance within a larger road system, and their current seismic resistance capacities.

Following the conclusion of the workshop, the ICSSC Lifeline subcommittee convened for a meeting. The committee decided that in view of limited design guidelines available in the lifelines area that the subcommittee should divide into specific task groups or areas to study available documents. After such study, the committee could then proceed to recommend interim guidelines for use in design of lifelines. As part of this effort, the Chairman called attention of the subcommittee to a workshop on "Disaster Prevention for Lifeline Systems" to be held in McLean, VA on May 14, 1984. This workshop will be hosted as part of the US-Japan Panel on Wind and Seismic Effects Task Committee on the subject of lifelines. It will include a program similar to the one of the just concluded workshop but will include presentation of Japanese research and practices. Members were encouraged to attend as part of their subcommittee activities. Attention was also called to a scheduled workshop on "Research Needs and Priorities in Lifeline/Earthquake Engineering" that will be held May 29-31, 1984 in Asilomar, CA. 


\section{Participants}

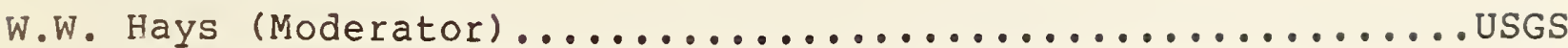

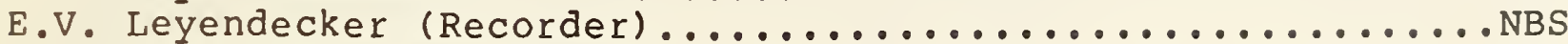

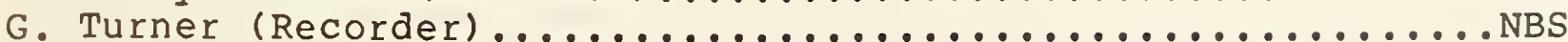

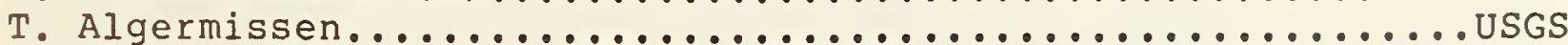

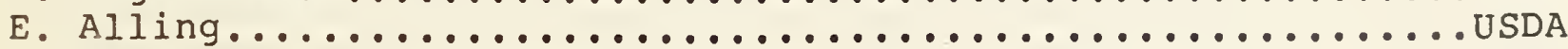

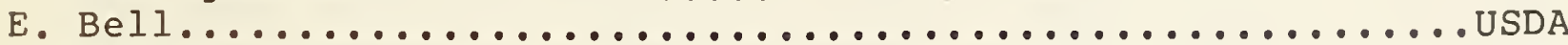

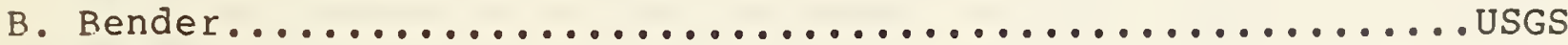

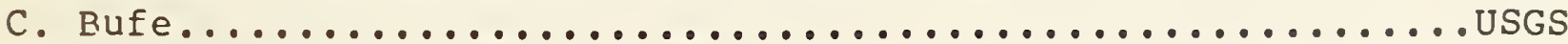

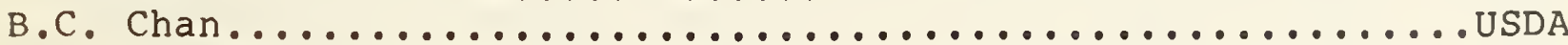

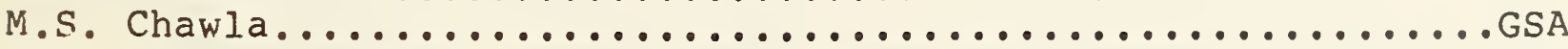

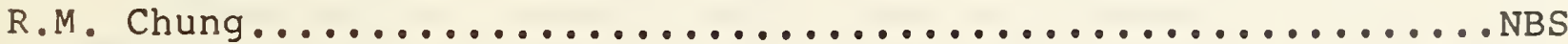

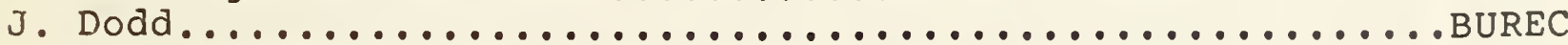

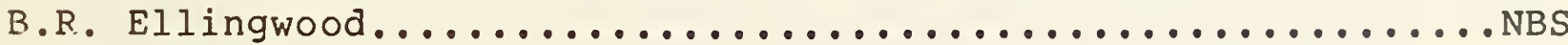

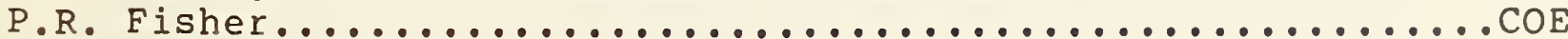

P. Gori.......................................... USGS

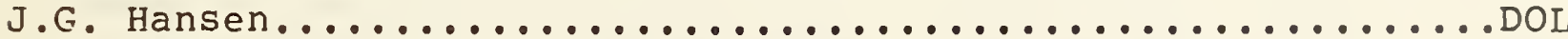

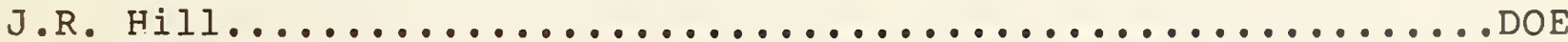

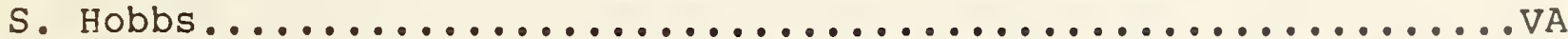

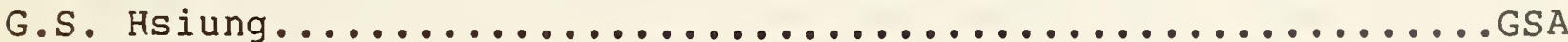

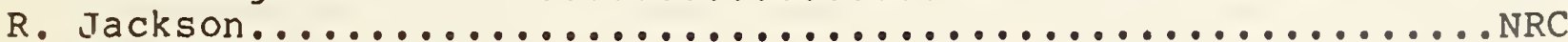

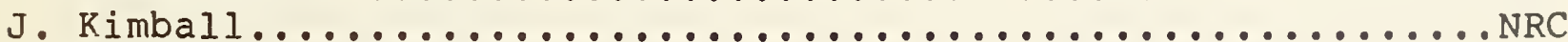

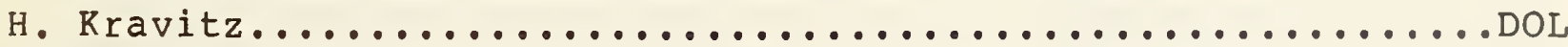

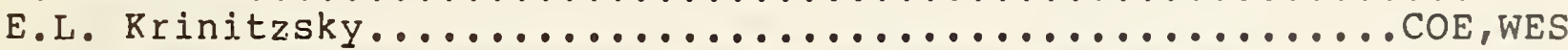

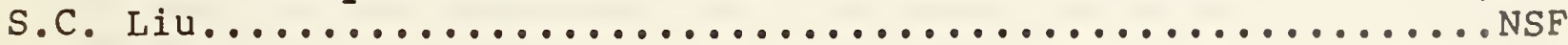

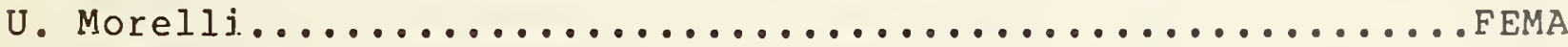

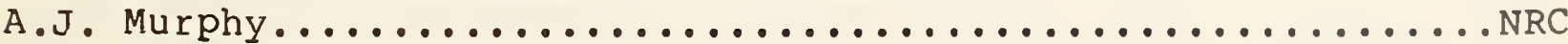

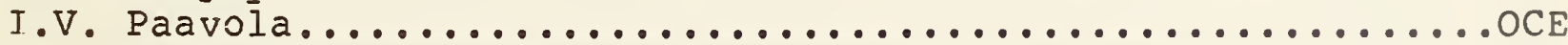

P.V. Patterson.................................. USDA

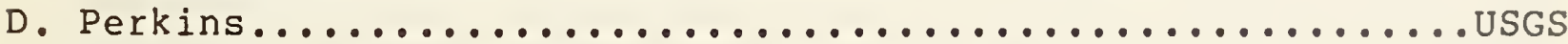

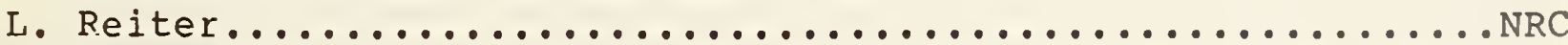

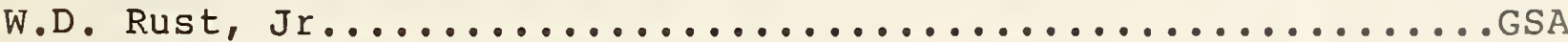

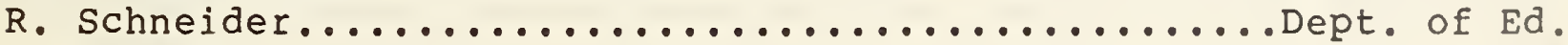

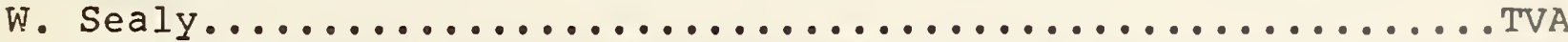

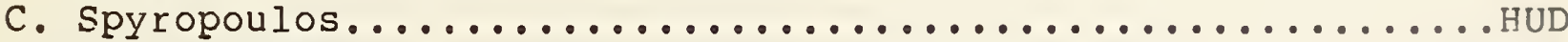

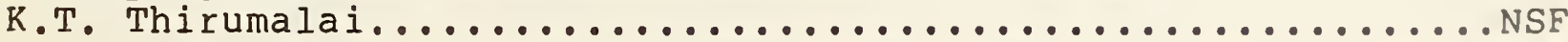

The moderator, Walter Hays, of the U.S. Geological Survey called the meeting to order and introduced Ted Algermissen of the U.S. Geological survey. Algermissen provided background for the construction of probabilistic ground shaking hazard maps.

Following his presentation, the workshop focused on a panel discussion with participants from the Federal agencies.

Algermissen noted the 1982 release of the USGS Open File Report 82-1033 entitled "Probabilistic Estimates of Maximum Acceleration and Velocity in Rock in the Contiguous united states [1]." This report contains a series of six maps, three for acceleration and three for velocity. Each series of three maps 
provide information for 10,50 , and 250 year exposure times. These maps are included as figures 4 through 9 of this report. (The following material is paraphrased from the USGS Open File Report and Algermissen's presentation. The interested reviewer is recommended this report for an in-depth treatment of seismic zone maps.)

The new maps provided by Algermissen and Perkins, et al. j.n 1982 differ significantly from an 1976 probabilistic bedrock acceleration map by Algermissen and Perkins [2] because of an increase in detail on the geological basis for seismic source zones. The 1976 probabilistic acceleration map was the basis for one of the ATC maps referred to in the Implementation Workshop. The new maps incorporate more seismotectonic information than was available for the earlier maps. The increase in information means that the ground shaking hazard is approaching an optimum level of precision beyond which it is difficult to go without a major earthquake or new infusion of knowledge.

Earthquakes are modeled in the source zones as fault ruptures, combinations of fault ruptures, and point sources. The particular model selected depends on whether or not the shock is large or small. The effect of variation of parameters such as point source versus fault zone and length of fault rupture was examined in the report. The report also considered different fault modeling techniques, various attenuation factors, variability in fault rupture length-magnitude relationship, and variability in attenuation functions. Soil effects are not incorporated in the maps. Algermissen also pointed out differences between the new maps and the earlier Algermissen and Perkins maps which served as the basis for the ATC report and subsequently the ANSI A58.1-1982 Standard. The new maps are considered an improvement in the application of probabilistic ground motion to earthquake-resistant design for two principal reasons: 1) the development of both acceleration ana velocity maps makes possible the estimation of bedrock response spectra at a site and comparison of spectra at any number of sites; 2) the change in earthquake hazard with exposure time can be estimated at any site because of the three available exposure times - namely, 10, 50, and 250 years. These exposure times can be correlated with the useful lifetime of a structure or facility (for example, an ordinary building has a useful life of about 50 years). Some specific problems still remain with certain geographical regions of the U.S. These include central Utah, the Puget sound, and most of the eastern U.S.

Following Algermissen's presentation, a number of Federal agency representatives were asked to identify some of their agency concerns and needs; technical issues associated with the construction of probabilistic ground shaking hazard maps and 
responsibilities of the agencies for earthquake-resistant design and construction. Discussion of various issues was interspersed with the presentations.

Robert Jackson of the Nuclear Regulatory Commission (NRC) indicated that he would like the earthquake hazard defined in a more stable sense; that is, he would like to see models defined that could be improved with new knowledge. NRC is trying to convert to a probabilistic rather than a deterministic approach. They are going away from the seismic zone map and are trying to estimate hazards at a specific site. In this regard, the various source zones and other relationships such as attenuation are a big problem in the East.

Paul Fisher of the Corps of Engineers indicated that zone maps are used to initiate studies for civil works. These may result in site-specific studies. If there are major zone changes, there will be many seismic hazard studies required. In regard to the USGS maps, the Corps will probably follow them if industry endorses the maps.

Jerry Dodd of the Bureau of Reclamation described the Bureau's approach for dams, distribution systems (such as canals, etc.), and buildings. The Bureau is interested in the new USGS maps and may incorporate them in their decision-making process about site-specific activities. At this time, dams require a site-specific study, their distribution systems are usually at the designer's discretion, and buildings are designed in terms of the local code level.

Steve Hobbs, representing the Veterans Administration (VA), indicated that the VA used national and local codes prior to the 1971 San Fernando earthquake. Following that earthquake, they initiated some site-specific studies and used a panel of experts to evaluate the results for each site. They believe the sitespecific evaluation study is best for their purposes.

Bruce Ellingwood described the National Bureau of Standards' (NBS) effort as the secretariat of the American National standards Institute committee that prepared ANSI A58.1-1982 "Building Code Requirements for Minimum Design Loads in Buildings and other Structures." The Standard supports a probabilistic approach to design. The seismic zone map in that report (figure I) is based on the results of the Applied Technology Council study which in turn were based on the 1976 Algermissen and Perkins report discussed earlier.

Charles Scheffey of the Department of Transportation indicated that the American Association of State Highway and Transportation officials (AASHTO) has endorsed a new set of criteria for bridges. The criteria was the result of an FHWA-sponsored effort with the Appliea Technology Council. The AASHTO group 
endorsed the approach but did not accept the map presented in the recommendations. Instead, they used a UBC zone map approach.

Ugo Morelii of the Federal Emergency Management Agency defined FEMA activities under the National Earthquake Hazards Reduction Program (NEHRP). He described the NEHRP efforts as a four agency activity (FEMA, USGS, NSF, and NBS). He described a trial design process that is currently underway for new buildings using, as a base, the Applied Technology Council requirements that have been discussed in several of the workshops. The objective of this effort is the preparation of a set of recommended provisions for new buildings issued as part of the NEHRP. FEMA usually uses USGS seismic maps in their earthquake preparedness activities and may use USGS-developed site-specific maps in providing aid to state and local officials after a major earthquake.

Ellis Krinitzsky from the Corps of Engineers voiced some opinions. He pointed out a number of potential problems such as those with expert opinions on seismicity. He felt that you could get any opinion you wanted by selecting a particular expert. He also voiced the opinion that extrapolation from historical data representing a short time (e.g., 100-200 years) might lead to some severe problems for long return periods. Krinitzsky solicited some discussion between him and USGS on maps.

E. V. Leyendecker of the National Bureau of Standards (NBS) offered his opinion that the variability in maps raises major questions. He felt seismic design procedures were easy once risk had been established. Variability in maps raises questions about the certainty in aescribing the risk.

The workshop closed with the note that there was considerable need for improvement on seismic risk on the national level and that there was need for an information clearinghouse to disseminate available information such as the type discussed in the workshop. 


\section{Participants}

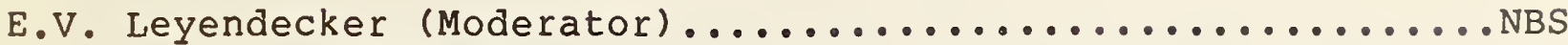

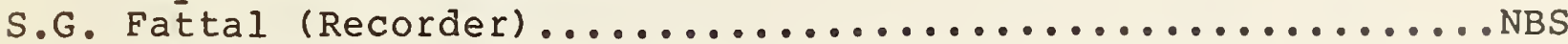

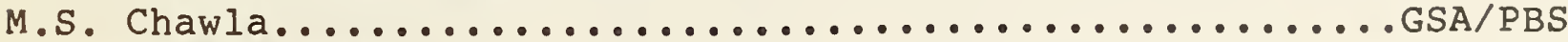

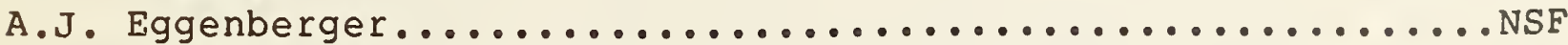

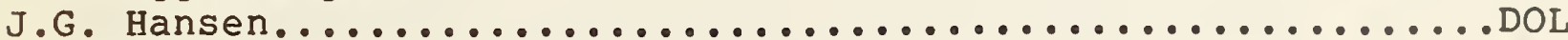

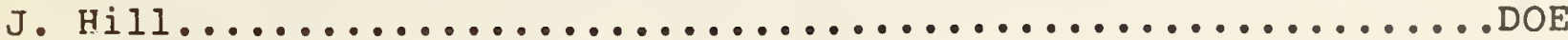

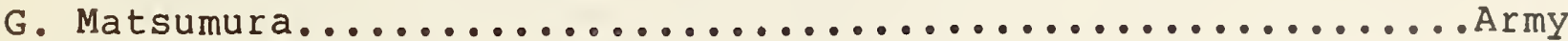

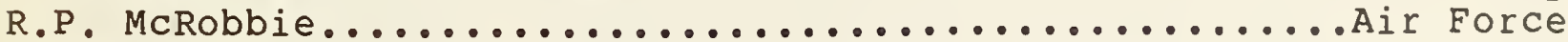

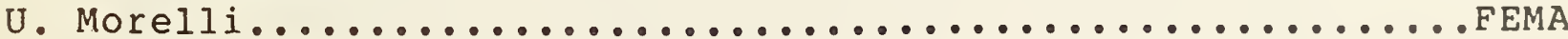

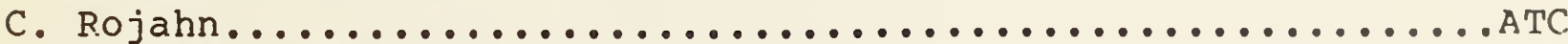

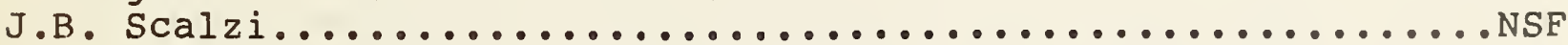

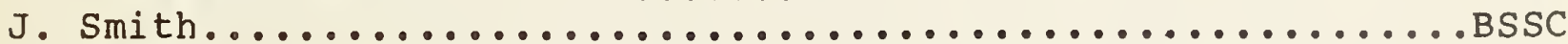

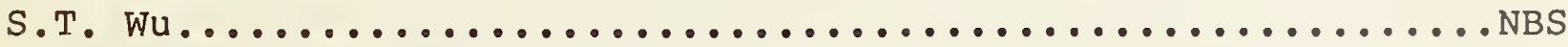

\section{WORRSHOP HIGHLIGHTS}

The workshop was sponsored by the ICSSC subcommittee on Standards for New and Existing Buildings (Subcommittee l) and moderated by its chairman, E.V. Leyendecker.

Presentations of selected research activities by the private sector followed by an overview of selected agency activities. The workshop began with opening remarks by Dr. Leyendecker on the National Earthquake Hazards Reduction Program. Diverse codes and standards cited, such as used by various Federal agencies, local jurisdictions, model codes, and consensus standards, served to highlight the need to work towards a unified approach to seismic design provisions. (The March 19 workshop cites much of this information.) With regard to existing buildings, the need to identify and solve some of the critical problems was cited. For example, it was noted that not much is known about the effectiveness of the widely used epoxy repair technique in the event of fire. The opening remarks were concluded with a presentation of damage due to several earthquakes and what might be anticipated.

James R. Smith, Executive Director of the Building Seismic Safety Council (BSSC), discussed the status of a project for identifying actions needed to abate the seismic hazards posed by existing non-Federal buildings. This is a joint venture between ATC, BSSC, and EERI. The plan is to develop issue papers in various areas related to hazardous existing buildings (eight such areas were defined), discuss these papers at a workshop and present the workshop proceedings and a plan of action to FEMA, the project sponsor. This will be a 12 -month effort, with the plan and final report scheduled to come out in October 1985. The issue papers will be available two weeks before the workshop 
which is scheduled in the latter part of March 1985. U. Morelli sees a key role for NBS in this effort to participate in the liaison group and to bridge Federal and private sector standards.

Chris Rojahn, Executive Director of the Applied Technology Council, spoke about the ATC 14 project on methodology for evaluation of the seismic strength of existing buildings. This three and one-half year, NSF-sponsored effort has been underway for two years and aims at developing a manual that will be applicable nationwide (Federal and private). The project engineering panel will consist of James Noland, Mete Sozen, government representatives and practitioners. Comments by Dr. Scalzi of NSF dwelt on selecting a well-balanced panel with regard to regional representation, academia, practitioners, and government agencies. The guidelines focus on some ten building types, with the methodology based on reformatted existing knowledge, plus some new ideas. A three-phase approach will be focused on preliminary screening, rapid evaluation, possibly involving some materials tests, and an in-depth evaluation. Both structural and non-structural aspects will be considered. Completion is targeted for June 1986. James Hill of DOE drew attention to an existing publication [9] which provides overviews from the plant manager's point of view.

Scalzi presented an overview of NSF activities. In addition to the ATC project noted above, FY 84 funded research projects encompass the following areas:

1. Effect of fire on epoxy repair.

2. Strengthening existing masonry buildings by drilling, inserting rebars, and injecting them with epoxy.

3. Study of concrete block infilled walls to prevent complete collapse.

4. How to combine new and old concrete in existing structures.

5. Effect of heat-strengthening of deformed steel members.

6. Developing hysteretic properties of wind-type connections to assess seismic behavior.

7. Research on reinforced concrete bridge girders.

8. UJNR testing of steel and concrete buildings to improve modeling for seismic behavior.

9. Seismic behavior of wood buldings.

10. Develop basic properties of unit clay masonry and mortars through tests. 
11. Nondestructive evaluation of existing buildings.

12. Cyclic response of anchor bolts.

13. Seismic response of composite masonry (brick-groutblock system).

14. Effect of shotcrete on masonry walls.

15. Seismic response of masonry piers.

16. Strength of masonry connections.

A.J. Eggenberger of NSF spoke about the "Base Isolation" approach to earthquake design and NSF interest in exploring this relatively new design philosophy. NSF will identify research needs in this subject within the next six months and come out with a timetable. Another area of interest to NSF identified was the behavior of nonstructural elements, such as ceiling systems, lighting systems, precast panels, cladding and glass. An articulated plan is envisaged within the next six to nine months.

The remainder of the session was dedicated to selected Federal agency activities on existing buldings, including current agency programs, future plans, problem areas, and agency needs.

Richard McConnell discussed the criteria used by the Veterans Administration (VA) in evaluating its buildings. The VA defines four priorities for strengthening buildings. For category 1 (major risk) buildings, VA requires that the facility attributes (good or bad) be identified. VA needs require that provisions be site-specific so that they may be used on a caseby-case basis.

James Hill described the DOE program. The Department has an upgrading program at Berkeley, including $\$ 20$ million to upgrade buildings damaged in the 1980 California earthquake. DOE is consistent with national codes and standards. A report titled "Site Specific Studies" will be issued as UCRL 53582.

George Matsumura discussed the Army's program in evaluating their structures. From among a total of 3,600 buildings, 17 were selected for evaluation by means of the Navy's manual which is compatible with DOD. Of these, seven buildings were identified as needing detailed structural analysis. Three buildings will be subjected to strengthening methods. The Army does have basic design guidelines for base acceleration (50 percent exceedance in 50 years and 10 percent in 100 years - inelastic mode). Their 
manual will be published in one year but a draft will be available in 3-4 months. CERL is doing the detailed study of the three buildings to develop strengthening methods and corresponding costs.

Information on evaluation and strengthening of existing buildings is limited. There are good case studies of techniques used but the information is not broadly applicable. This is due in part to the variability in construction materials, construction techniques, and general practices that have naturally occurred through the years. Evaluations are being conducted and strengthening efforts are being made out of necessity but they are being done based on limited information. The research effort in the area has been fragmented thus far and there is general agreement on the need to define the problems and develop a coherent research plan. Both FEMA and NSF are giving increasing priority to work in this area. 


\section{CLOSURE}

The workshops sponsored by the ICSSC were intended to provide a forum for presenting and discussing recent developments on various earthquake hazards mitigation topics and for presenting and discussing agency practices and concerns.

Most agency representatives present agreed that common Federal seismic provisions are desirable provided they allow flexibility for specific agency needs. There was general agreement that uniformity would probably not occur without a specific requirement for it, such as an executive order.

The lifelines workshop concluded that design guidelines for use in design and construction of the wide variety of lifeline facilities are limited. Existing documents should be studied for determining what existing guidelines can be used on an interim basis. The seismic zoning workshop participants concluded that there is a lot of recent information available for use in studying updating of risk maps. This information should be used to update the maps and allow development of some recommended maps. There is a need for people working in the field of risk mapping to have frequent exchanges of informtion.

The workshop on existing buildings concluded that the problem of such structures is extensive and the available data for evaluation and approaches to strengthening are limited. At the same time, work is proceeding in both of these areas in spite of the limitea knowledge because of the need to take actions. 


\section{REFERENCES}

1. Algermissen, S.T., et al., "Probabilistic Estimates of Maximum Acceleration and Velocity in Rock in the Contiguous United States," Open File Report 82-1033, U.S. Geological Survey, Denver, Co, 1982.

2. Algermissen, S.T. and Perkins, D.M., "A Probabilistic Estimate of Maximum Acceleration in Rock in the Contiguous United States," Open File Report 76-416, U.S. Geological Survey, Denver, Co, 1976.

3. "Amendments to ATC 3-06 Tentative Provisions for the Development of Seismic Regulations for Buildilngs for Use in Trial Designs," NBSIR 82-2626, National Bureau of Standards, Washington, DC, 1982 .

4. Applied Technology Council, "Tentative Provisions for the Development of Seismic Regulations for Buildings," SP-510, National Bureau of Standards, Washington, DC, 1978.

5. "BSSC Program on Improved Seismic Safety Provisions, 3 Volumes," Building Seismic Safety Council, Washington, DC, 1984 .

6. "Building Code Requirements for Minimum Design Loads in Buildings and Other Structures," American National Standards Institute Inc., New York, New York, 1972.

7. "Building Code Requirements for Reinforced Concrete (ACI 318-83)," American Concrete Institute, Detroit, MI, 1977.

8. "Design Guidelines, Earthquake Resistance of Buildings," PBS (PCD) :DG.1, Volume 1, General Services Administration, Public Building Service, Washington, DC, March 1978.

9. Eagling, Donald G., "Seismic Safety Guide," OBL-9143, Lawrence Berkeley Laboratory, University of California, Berkeley, California, September, 1983.

10. Forell, N.F., "Developments in Earthquake Design Codes," San Francisco, California, 1981 .

11. Harris, J.R., Leyendecker, E.V., et al., "Draft Seismic Standard for Federal Buildings," NBSIR 81-2195, National Bureau of Standards, Washington, DC, 1981.

12. "Lateral Force Design Requirements for VA Hospitals," Veterans Administration, Washington, DC, 1974. 
13. "Minimum Design Loads for Buildings and Other Structures," American National Standards Institute Inc., New York, New York, 1982 .

14. "Plan for a Trial Design Program to Assist Amended ATC 3-06 Tentative Provisions for the Development of Seismic Regulations for Buildings," NBSIR 82-2589, National Bureau of Standards, Washington, DC, 1982.

15. "Recommended Lateral Force Requirements and Commentary," Structural Engineers Association of California, San Francisco, California, revised 1975.

16. "Seismic Design for Buildings," Department of the Army, Navy, and the Air Force, TM 5-809-10, NAV FAC P-355, AFM 88 - 3, U.S. Government Printing Office, Washington, DC, 1982 .

17. "Uniform Building Code," International Conference of Building Officials, Inc., Whittier, California, 1973.

18. "Uniform Building Code," International Conference of Building Officials, Inc., Whittier, California, 1982. 
American Association of State Highway and Transportation Officials (AASHTO)

American Concrete Institute (ACI)

American National standards Institute (ANSI)

American Society of Civil Engineers (ASCE)

American Society of Mechanical Engineers (ASME)

Applied Technology Council (ATC)

Building Seismic Safety Council (BSSC)

Bureau of Reclamation (BUREC)

Construction Engineering Research Laboratory (CERL)

Corps of Engineers (COE)

Department of Agriculture (DOA)

Department of Defense (DOD)

Department of Energy (DOE)

Department of Labor (DOL)

Department of Transportation (DOT)

Earthquake Engineering Research Institute (EERI)

Environmental Protection Agency (EPA)

Federal Emergency Management Agency (FEMA)

General Services Administration/Public Building Service (GSA/PBS)

Housing and Urban Development (HUD)

Interagency Committee on Seismic safety in Construction (ICSSC)

National Aeronautics and Space Administration (NASA)

National Bureau of Standards (NBS)

National Earthquake Hazards Reduction Program (NEHRP) 
National Science Foundation (NSF)

Naval Facilities Engineering Command (NAVFAC)

Nuclear Regulatory Commission (NRC)

Office, Chief of Engineers/Waterways Experiment Station (OCE/WES)

Structural Engineers Association of California (SEAOC)

Technical Council on Lifeline Earthquake Engineering (TCLEE)

Tennessee Valley Authority (TVA)

Uniform Building Code (UBC)

U.S. Department of Agriculture (USDA)

U.S. Geological Survey (USGS)

U.S./Japan Panel on Natural Resources (UJNR)

Veterans Administration (VA) 
Table 2. Approximate Relation of ANSI Zones with ATC Map Areas (ANSI A58.1)

ATC Map Areas

7

5,6

3,4

2

1

\section{ANSI Map Zones}

4

3

2

1

0

Table 3. Z Coefficients

\begin{tabular}{lccccc}
\hline Design Criteria/Seismic zone & 0 & 1 & 2 & 3 & 4 \\
\hline SEAOC Z-Factor* & - & - & - & - & 1 \\
ANSI Z-Factor & $1 / 8$ & $3 / 16$ & $3 / 8$ & $3 / 4$ & 1 \\
UBC Z-Factor & 0 & $3 / 16$ & $3 / 8$ & $3 / 4$ & 1 \\
Tri-Service Z-Factor & 0 & $3 / 16$ & $3 / 8$ & $3 / 4$ & 1 \\
* SEAOC refers only to a Z-factor of 1 for the highest \\
seismic risk area.
\end{tabular}


Table 4. Current Agency Seismic Provisions

1. Does the agency reference any existing code or standard in lieu of developing agency provisions? $\mathrm{Y} / \mathrm{N}$

2. If YES, which one?

Code/Standard
Uniform Building Code -
Basic Building Code
Standard Bulding Code
ANSI A58.1
Local/State Code
Other

Remarks:

3. Does the agency reference the document in item 2 without modifications? $\mathrm{Y} / \mathrm{N}$

If NO, how are the modifications obtained and how are they maintained and kept up to date?

4. Does the agency develop its own provisions? $\mathrm{Y} / \mathrm{N}$ If YES, how are they developed and how are they maintained? 
Table 5. Agency Policy and/or Requirements

1. Are the seismic provisions used as the result of agency policy, legislation, etc.?

2. What actions (policy change, legislation change, etc.) would be necessary to change or modify current requirements. 


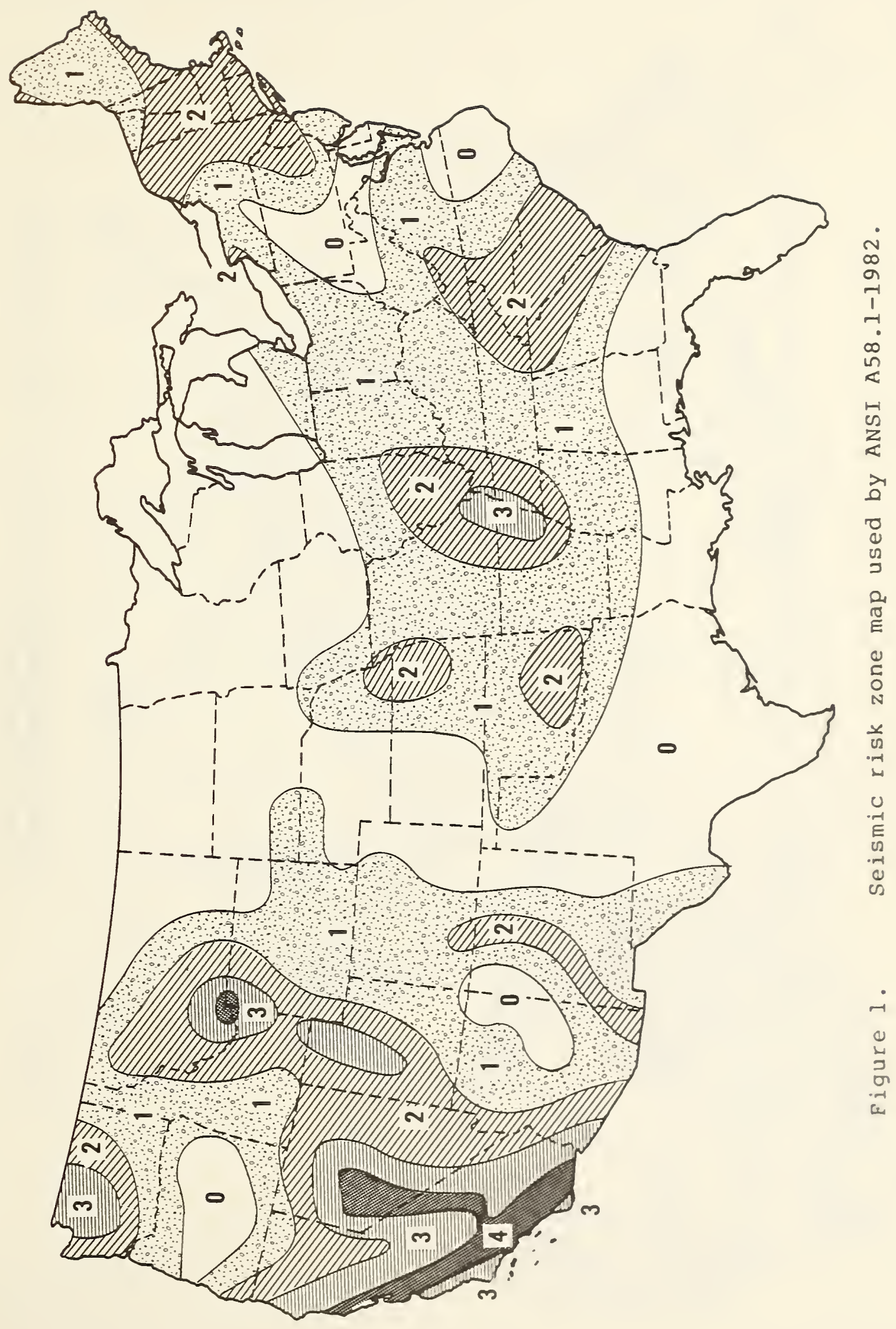




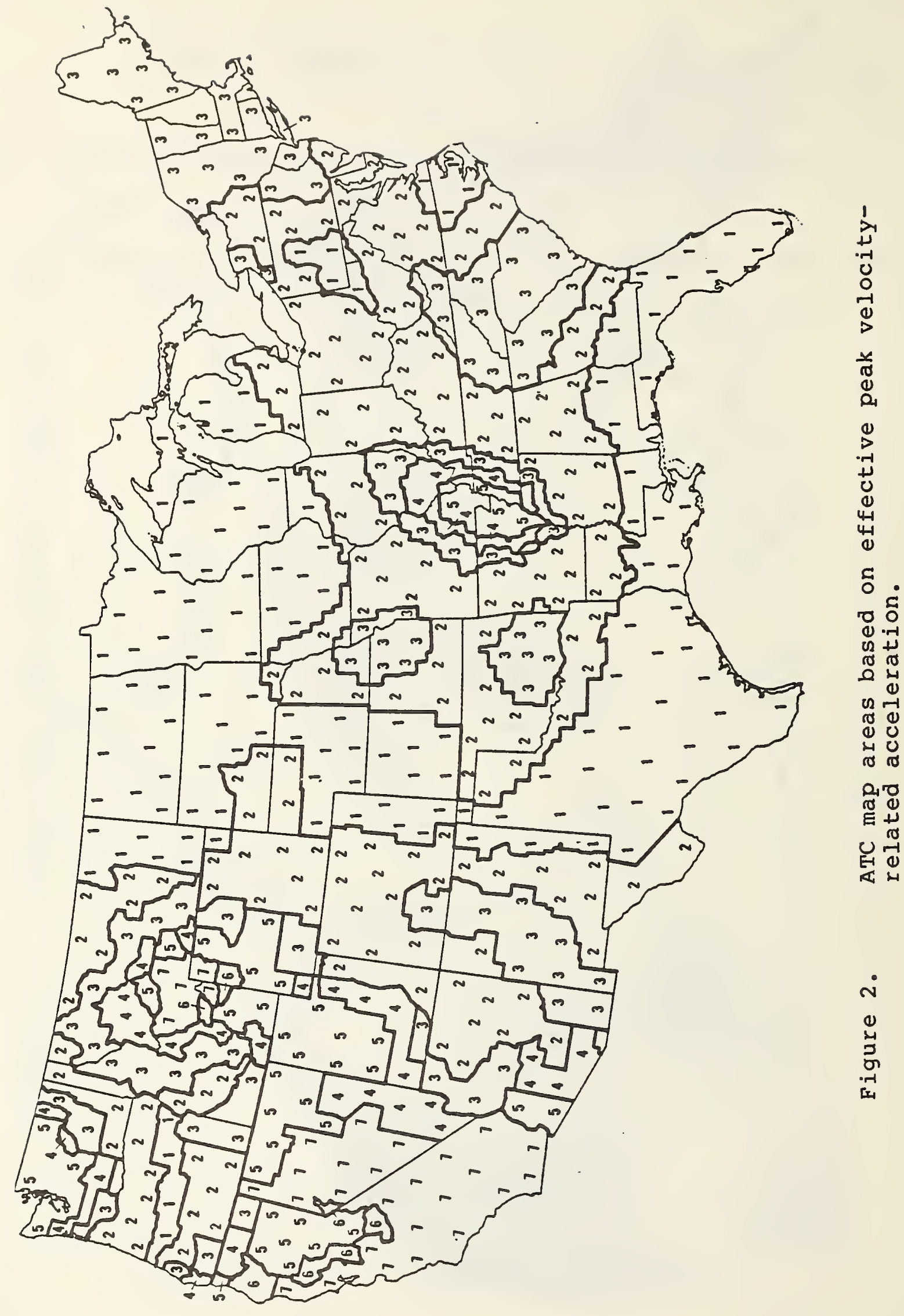




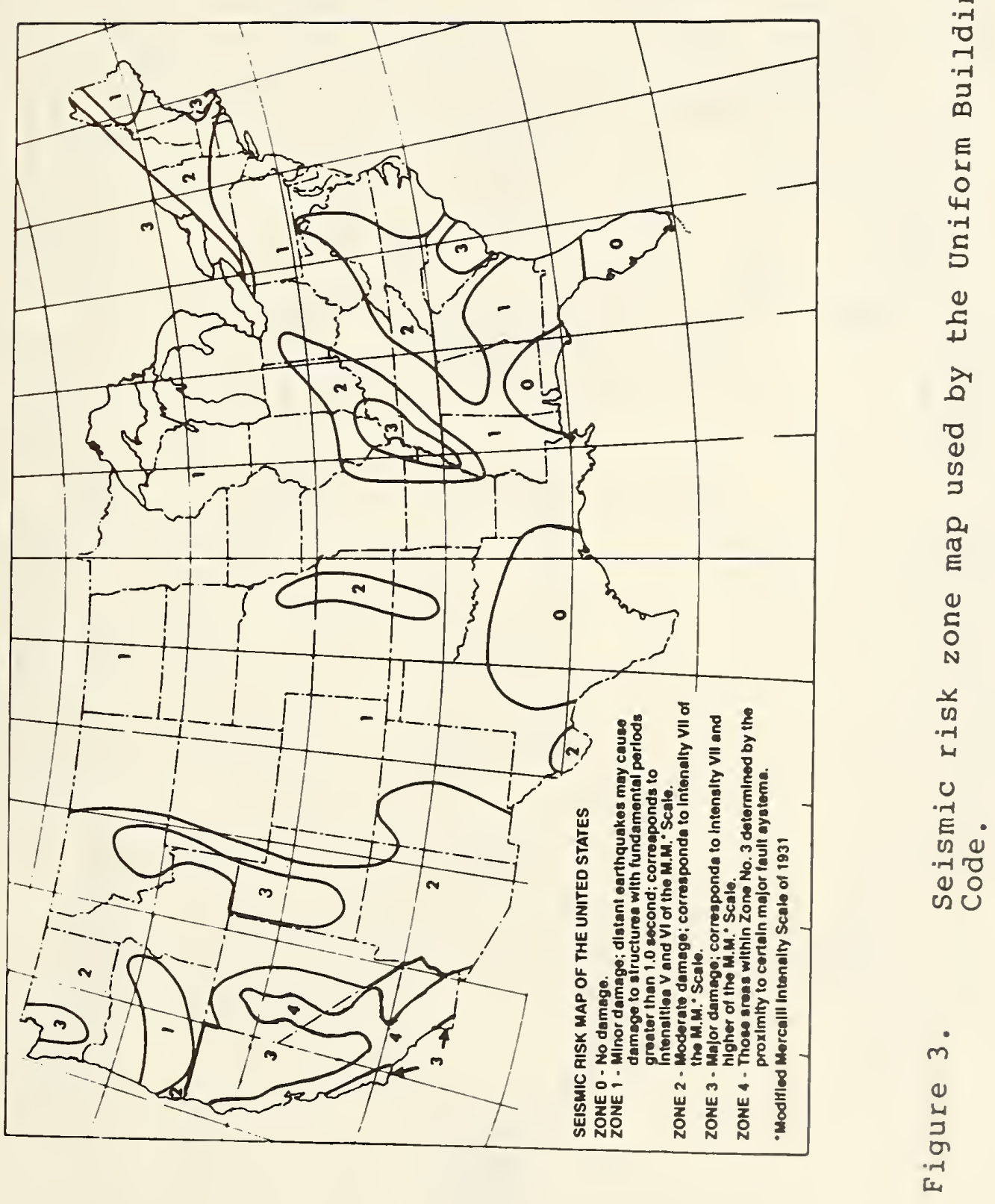




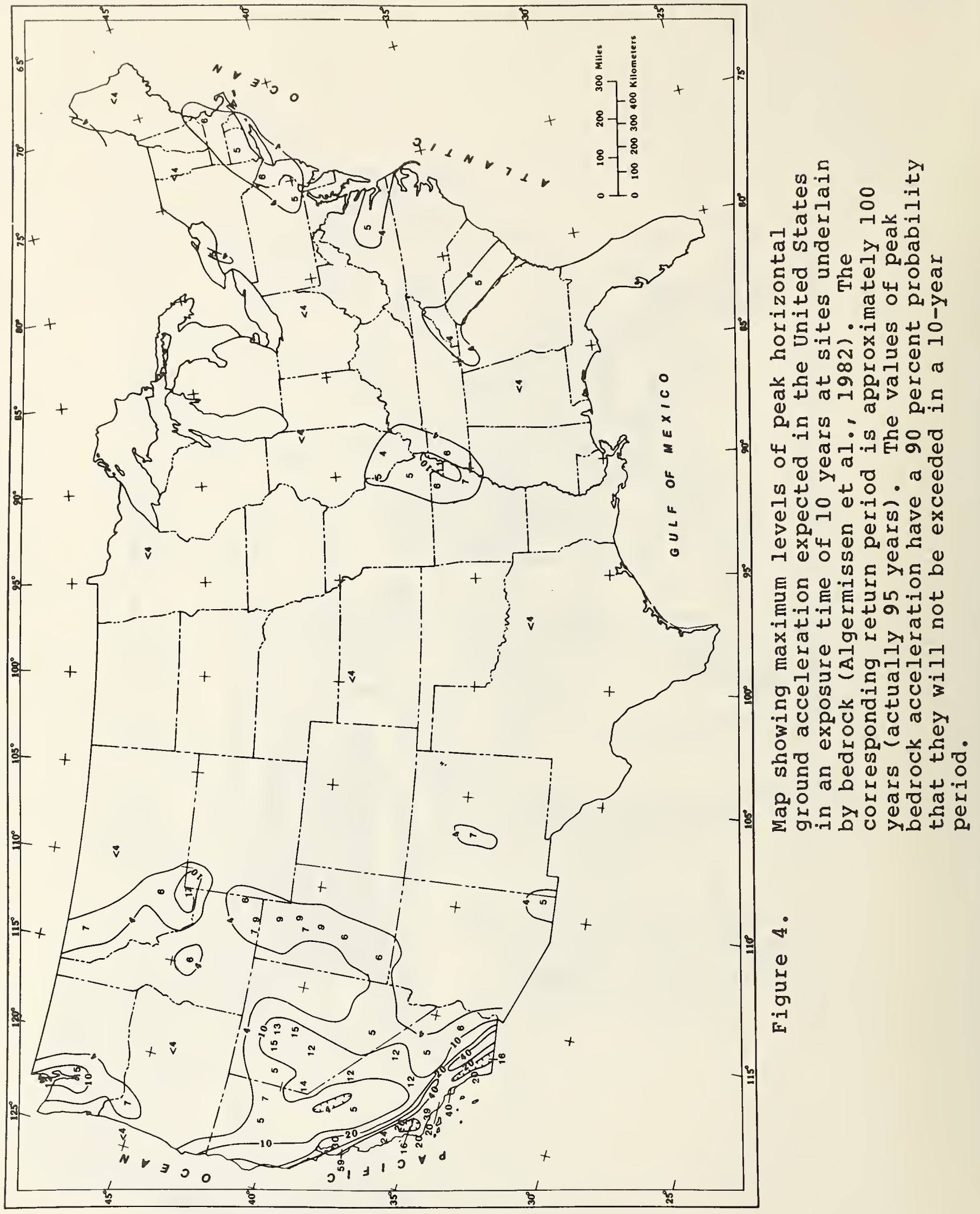




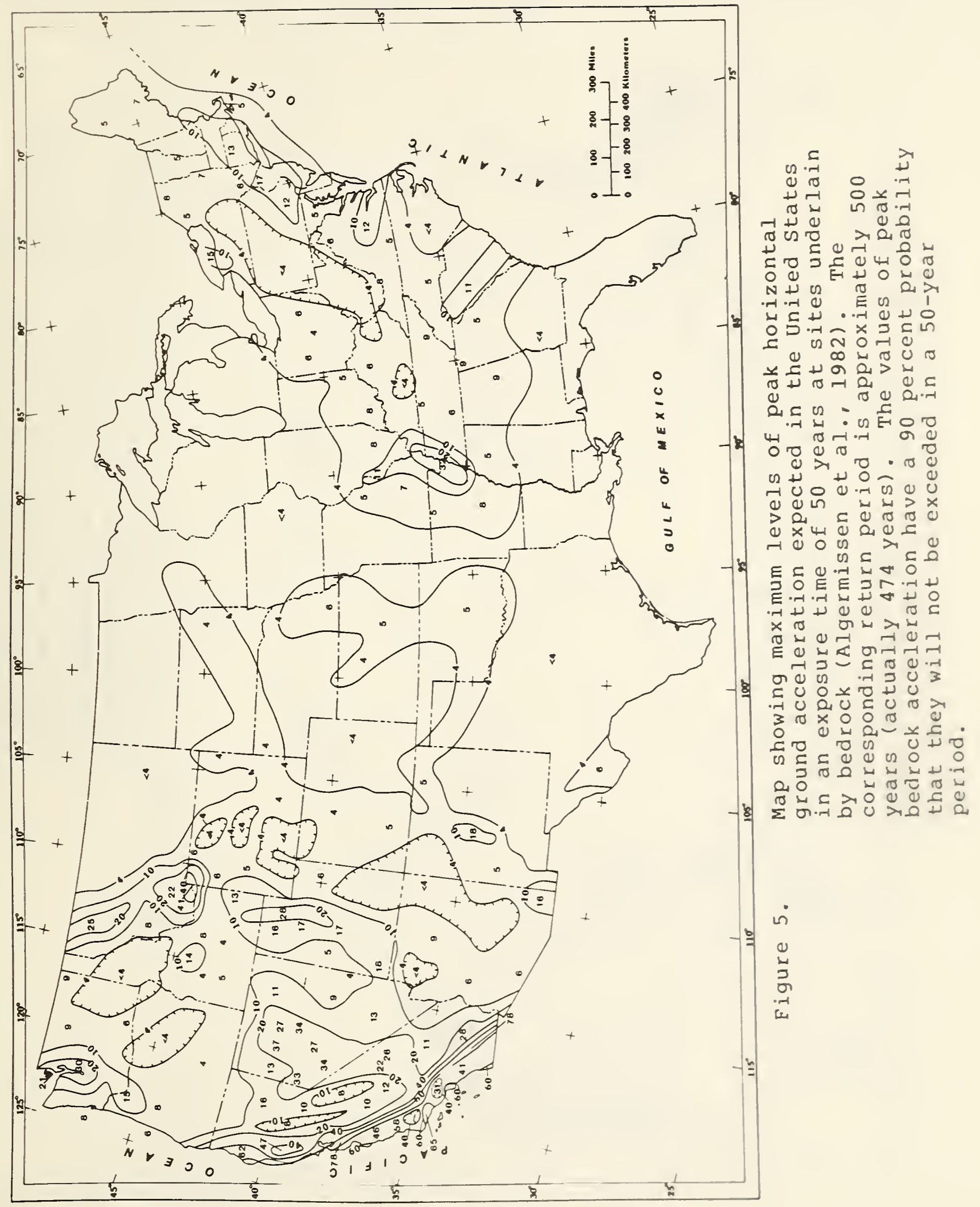




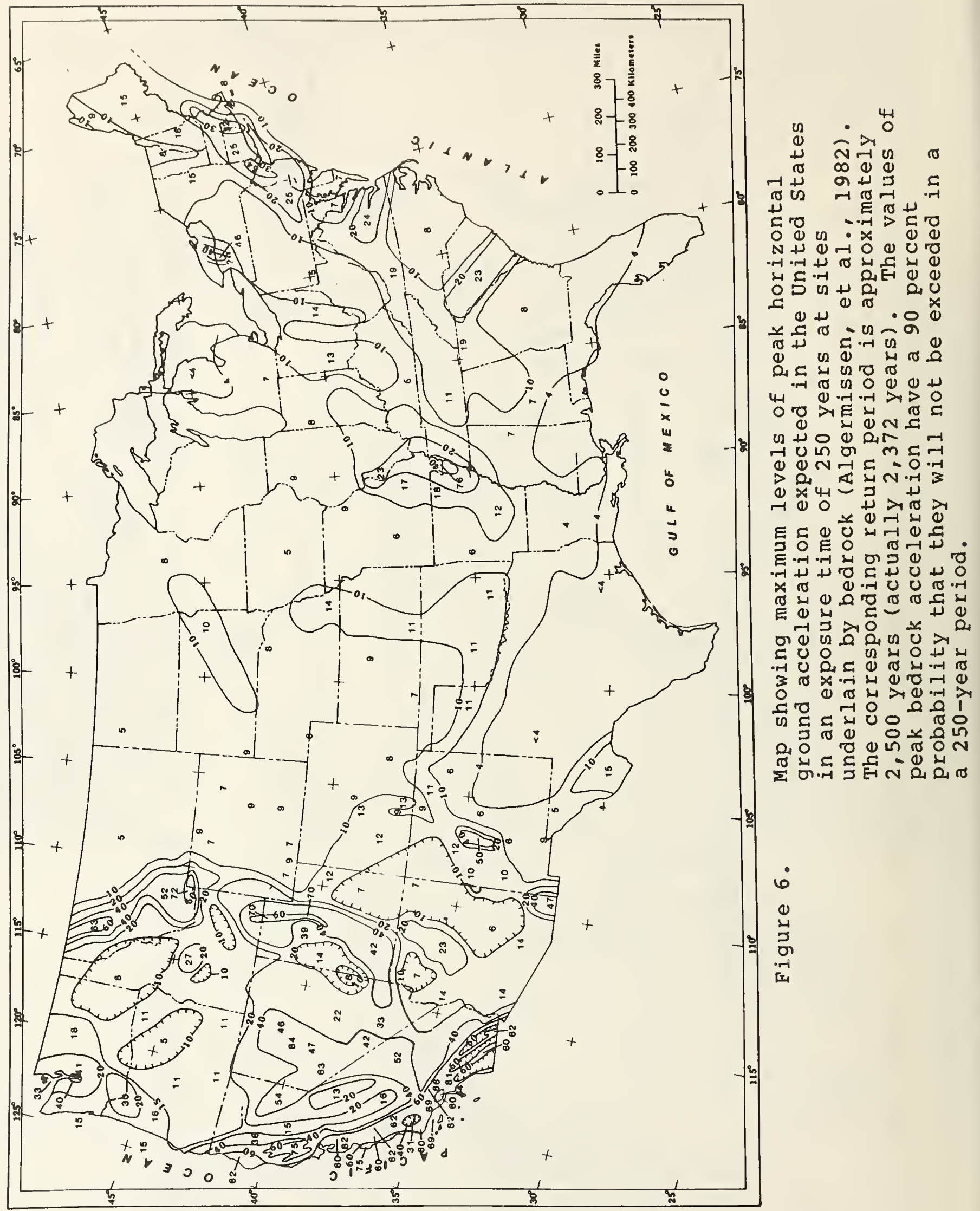




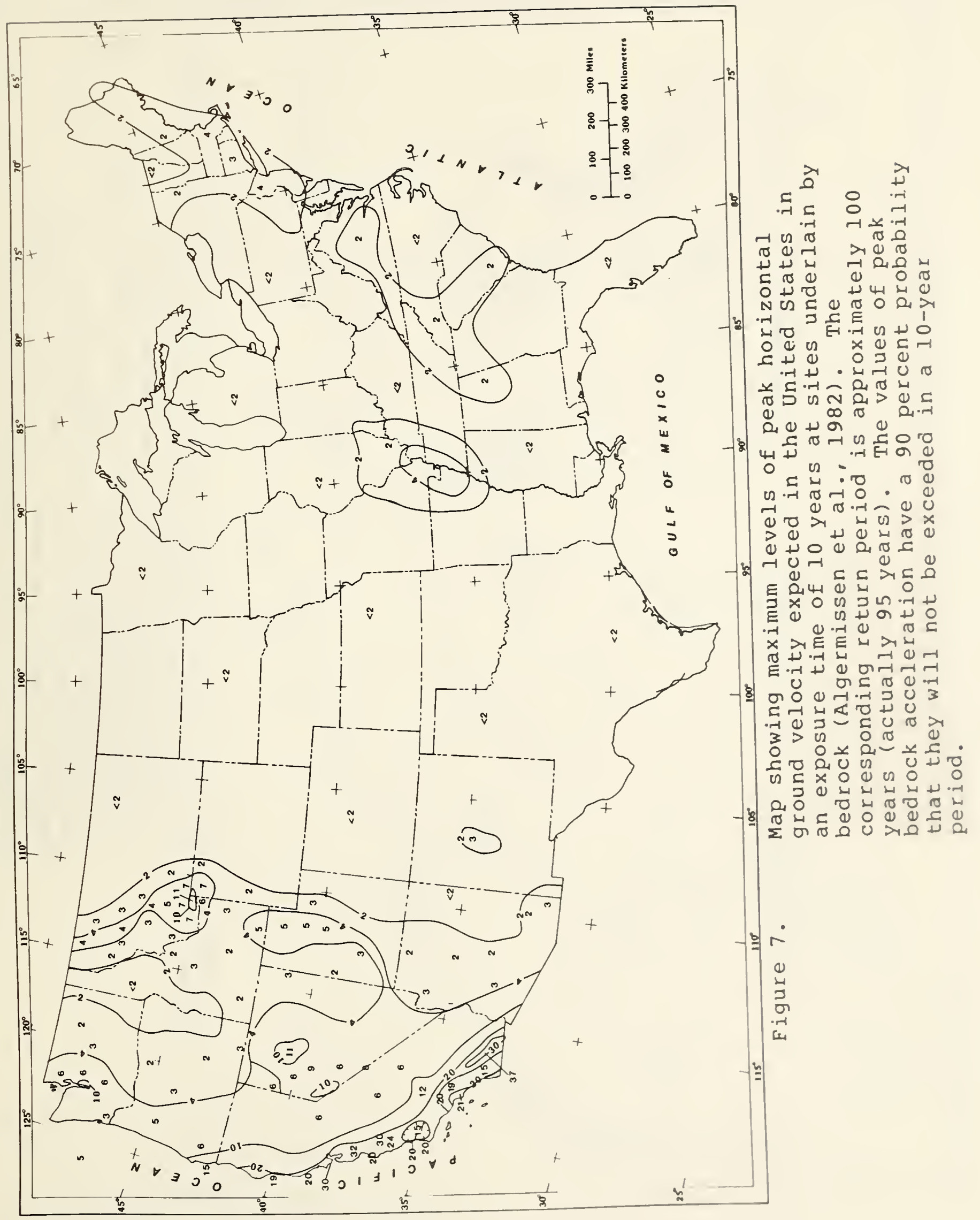




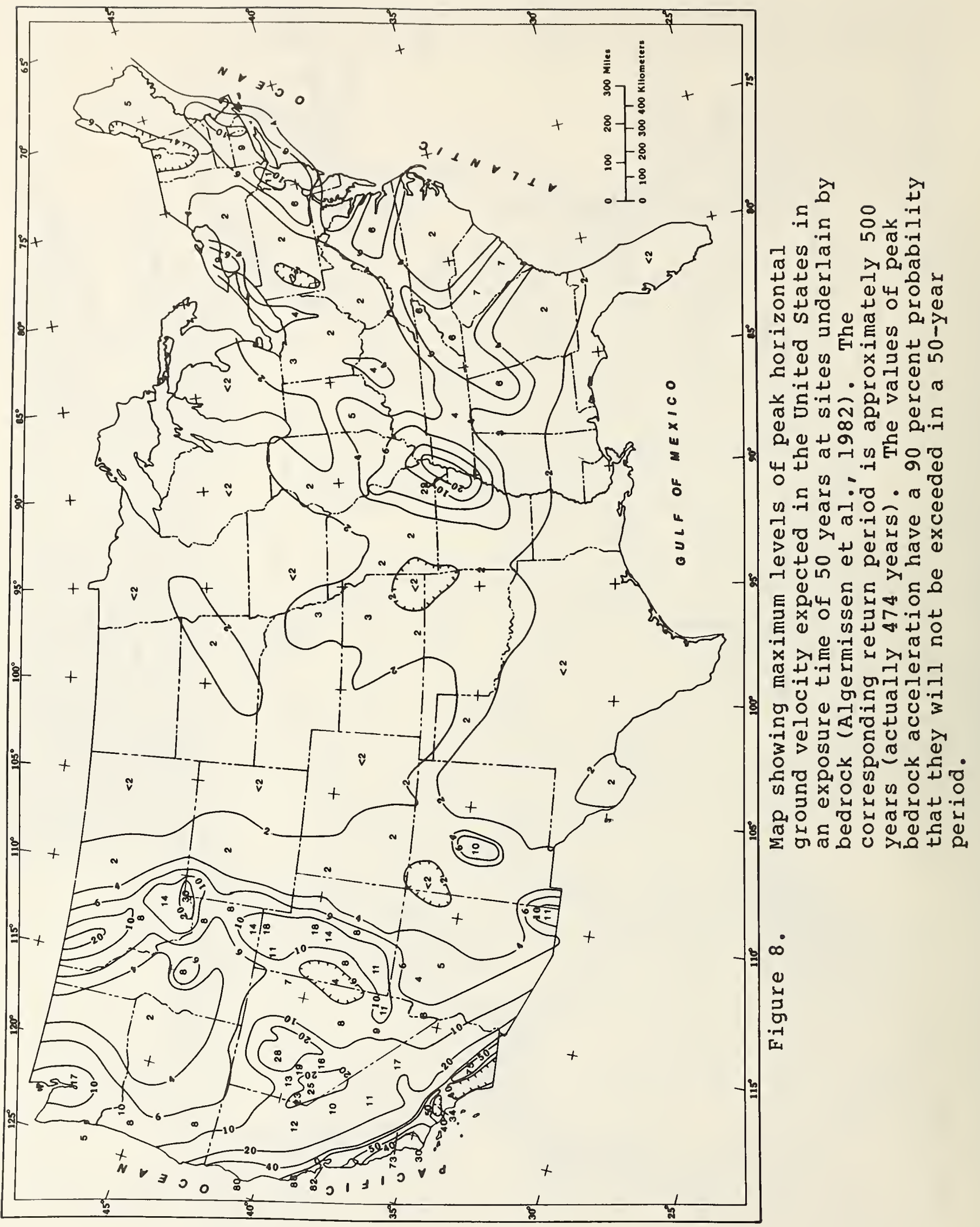




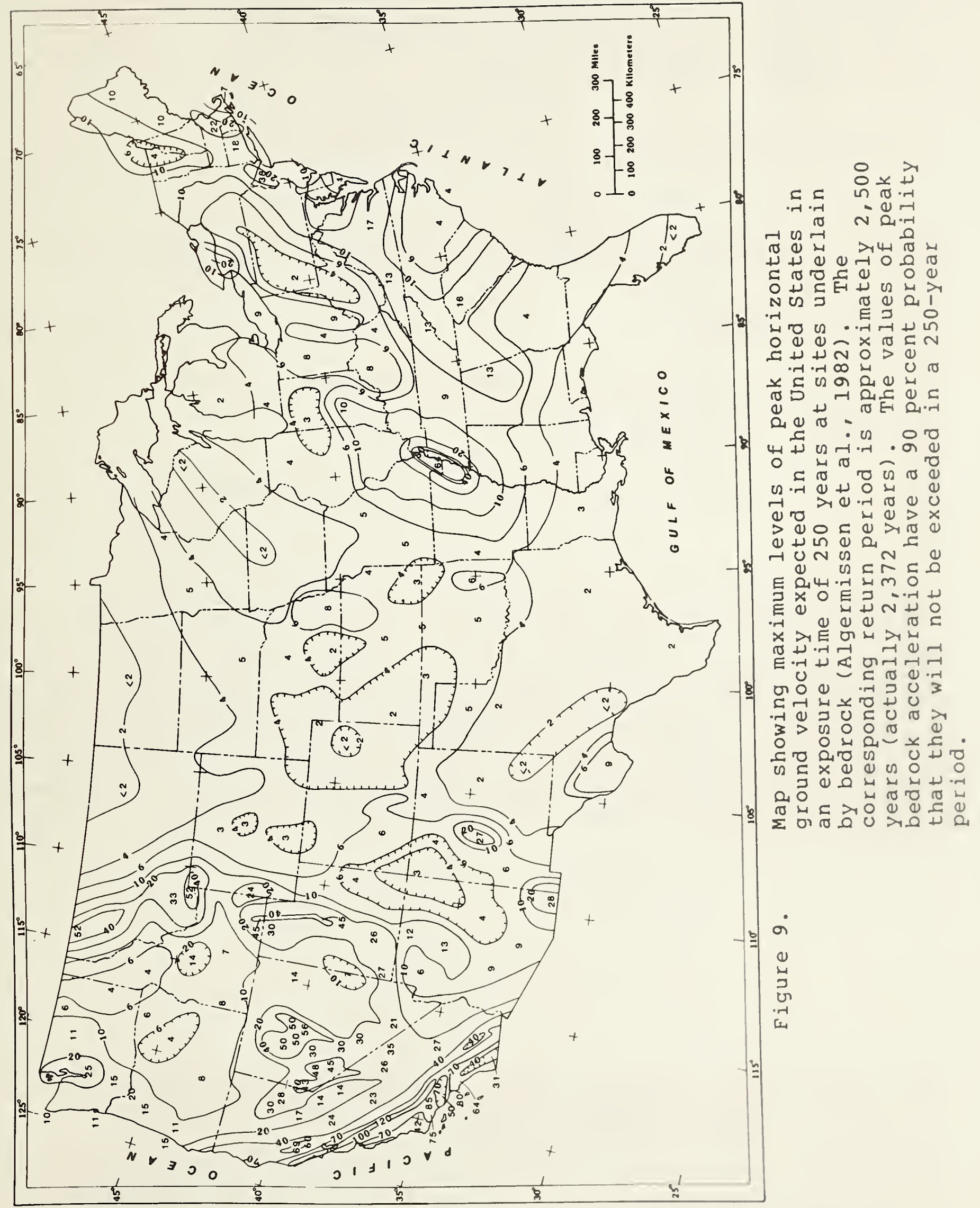


U.S. DEPT. OF COMM,

BIBLIOGRAPHIC DATA

SHEET (See instructions)

4. TITLE AND SUBTITLE
1. PUBLICATION OR
REPORT NO.

NBSIR 85-3161
2. Performing Organ. Report No.1 3. Publication Date

May 1985

Workshops Convened by the Interagency Committee on seismic safety in Construction During 1984

5. $\operatorname{AUTHOR}(S)$

Edgar V. Leyendecker, George E. Turner, and S. George Fattal

6. PERFORMING ORGANIZATION (If joint or other than NBS, see instructions)

7. Contract/Grant No.

NATIONAL BUREAU OF STANDARDS

DEPARTMENT OF COMMERCE

WASHINGTON, D.C. 20234

8. Type of Report \& Period Covered

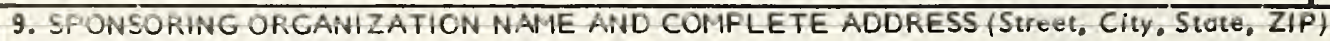

Federal Emergency Management Agency

Washington, DC 20742

10. SUPPLEMENTARY NOTES

Document describes a computer program; SF-185, FIPS Software Summary, is attached.

11. ABSTRACT (A 200-word or less factual summary of most significant information. If document includes a significant bibliography or literoture survey, mention it here)

In an effort to inform Federal agencies about the most recent development on various earthquake hazards mitigation topics, informal workshops were convened by the Interagency committee on seismic safety in construction in Washington, DC during 1984. This report presents summaries of the workshop series which included the subjects of implementation of seismic provisions for Federal agencies, lifelines, seismic risk maps, and evaluation of existing buildings. The summaries provide an overview of the major topics discussed. Where applicable, recommendations that resulted are given.

12. KEY WORDS (Six to twelve entries; alphabetical order: capitalize only proper names; and separate key words by semicolons) Buildings; building design; codes and standards; earthquake; existing buildings; Federal workshops; lifelines; seismic zoning.

\section{AVAILABILITY}

$\mathrm{x} \times \mathbf{x}$ Unlimited

$\square$ For Official Distribution. Do Not Release to NTIS

[- Order From Superintendent of Documents, U.S. Government Printing Office, Washington, D.C. 20402.
14. NO. OF

PRINTED PAGES

43

15. Price

$\$ 8.50$ 

